DOI: $10.1515 /$ hssr -2015-0010

\title{
Modern Finance, Moral Crisis
}

Tiberiu Brăilean

"Alexandru Ioan Cuza" University of Iasi, Romania

Modern finance has become a very complicated field, which raises many questions about its economic and social mission. The current financial system is discredited. People working here have no financial credibility; ethics and the sociology of finances have been abandoned, but the need for money remains, and so do all the conditionings created by financiers for the production of money. It is necessary to reform financial institutions and practices, starting from the core principle that money should serve the economy and society and not the other way round. Financial and communication technologies must be modernized to make microfinance, for example, reach the poorer. New and more flexible types of loans have to be designed. Then, if all spiritual traditions condemn interest, or usury, why do we practice it with such zeal (except for the Islamic financial system)?

We found that through some financial engineering, money can make money, in other words, money can be made without working. For this purpose, we have created a whole scaffolding of rules and instruments, institutions and a whole science. How do authors such as this Shiller imagine that this castle made of cards, this type of casino economy, can withstand a la longue? Only fools and those interested can believe that. They talk about "participatory forms (!) of using risk capital". In other words: "Give us your money to play the roulette." Losses must be socialized, right? The internet is full of sites of "crowd funding" or "spontaneous collective financing".

Public finances have a predominant public dimension, but they have been largely diverted towards private interests, so they need to be 
reinvented, starting from their legal infrastructure. We need a new financial literacy. Who sets the rules? Politicians are the first who need to understand and write new letters. We need good macroeconomists to develop sound economic policies, a terrible challenge; we need new pension schemes, social benefits and many other institutions built on the principle of intergenerational risk sharing, but with updated rules, avoiding the famous speculative "bubbles".

The belief that prices cannot fall has caused a mass phenomenon, but it must be abandoned. Such bubbles must be detected in time and defused before they infect the entire economy. Pricing models for capital assets and intricate formulas to calculate option prices can enrich you, but the financial sector is not only concerned with this, or just with risk management; it must deal with the asset of servicing company objectives. The financial system must be democratized by extending its benefits through more imagination, innovation, skill and selflessness. Finance must be reinvented.

Michael Lewis in his latest book, Flash Boys: $A$ Wall Street Revolt (W. W. Norton \& Company, New York, 2014) pointed out that Wall Street's culture is twofold harmful. First, the preeminence of short-term gains over long-term gains will always encourage risky behaviours and therefore, it will corrupt economic incentives. Second, many bankers do not know what the market is going to do in the future, while they pretend to know more than they are prepared to see. Governments have tried to solve these problems by adopting better regulations and, in many cases, quantitative relaxation mechanisms (Idem, 2014). This issue emphasises a dangerous feature of the financial system: many bankers' ignorance of complex knowledge and care for the future are hostile ingredients that transform the markets' volatility, through spillover effects, into economic and financial crisis and social anomy.

We live in a world of financial capitalism, a world driven by money and adjacent institutions which appear to be defective and unjust to many of us. It is an invented, partly virtual world, which is ceaselessly refashioning reinvents itself, though not always thoughtfully. The characteristic financial system must be expanded and democratised, humanised, moralised, so that its impact on ordinary people can be mostly positive. In addition, the system should be more transparent, so 
that information and resources could be used actively and intelligently by all interested persons, almost permanently.

The current financial establishment must abandon cynicism, selfishness and aggression. The new financial inventions need rationality and humanism. Only in this way can blatant inequalities be reduced. Otherwise, social movements, either from the left or from the right, can reignite, leading to chaos. This brings a charge to the conspiracy between the government and the leading financial sector, plus an excessive concentration of money and power in the key financial centres, while the others perform the work. Financial kings dominate governors like puppets, for mutual enrichment. This is what has caused the crisis.

If we do not attack its deep roots, the crisis can repeat itself. Why were the culprits not punished? The Inquiry Commission of the Financial Crisis in the US Government described the booms as "madness". In the US, people gathered using social media, but went from peaceful demonstrations to fights with thousands of participants, whose motivation nobody understands. Is that so? No one thinks about the frustrations of those senseless people, empoverished by the crisis, about the real shortcomings within the financial system and about the aberrant behavior of its managers. Why not adopt corrective laws and regulations?

In 2008, The Telegraph announced that "Lehman Brothers' British staff reacted with fury when told that colleagues at Lehman's New York office were expected to share in a $\$ 2.5$ billion bonus bonanza while they would be paid just until the end of the month" (Butterworth, 2008). While other examples should be easy to list, some bankers considered $t$ bonus controversy an error. AIG CEO Robert Benmosche declared that this scenario "was intended to stir public anger, to get everybody out there with their pitch forks and their hangman nooses, and all that-sort of like what we did in the Deep South [decades ago]. And I think it was just as bad and just as wrong" (Daily Finance Staff, 2013). The rewards for finance people are enormous judged against their effort, and inequalities are blatant. In addition, governments have saved fraudulent rich bankers with money from taxes from the poor, which is downright scandalous. Is that capitalism? How healthy and how sustainable is the rise in credit of the economy? Does it solve or does it 
create more risks? Where are Ricardo's savings? Not to mention the fact that most debts are made for weapons, for self-destructive technologies. How can such systems not implode? Instead of returning to the great classical equilibrium, it is still virtually innovating. How to integrate fair and moral behaviour in the culture of Wall Street? A bomb can solve the problem. History teaches us that great crises are overcome through war. The irony is that, given the degree of interconnectivity in the system, we do not need less finances, but a better system, because generalized suspicion hinders good innovation in healthy financial instruments. The current political climate is also an obstacle. And money can be neither better nor worse than the society it represents. Let's look in the mirror...

\section{Biographical note}

Tiberiu Brăilean (1960-2015) was a writer and professor at the "Alexandru Ioan Cuza" University of Iasi, Romania, Director of the Centre of Transdisciplinary Research of the "Alexandru Ioan Cuza" University and an active member of CIRET (Centre International de Recherches et Etudes Transdisciplinaires), Paris. His main area of interest was centered on a holistical approach to different sciences and religions, towards the recovery of unity beyond fragmentary appearance. Author of several national economic and social development strategies, he wrote over 800 articles, 18 books as a single author and 10 as a coauthor. Among his most recent books are: Sisteme economice / Economic Systems (2009), Criza pămintului plat / Flat Earth Crisis (2009), Teoeconomia / Theoeconomy (2011), Economie politică / Political Economy (2012), Omeconomia /Human-Economy (2012), Teomeconomia / Theo-Human-Economy (2013), Fericitor/Blissful (2014), Economia hgolotropică/The Holotropic Economy (2015). 